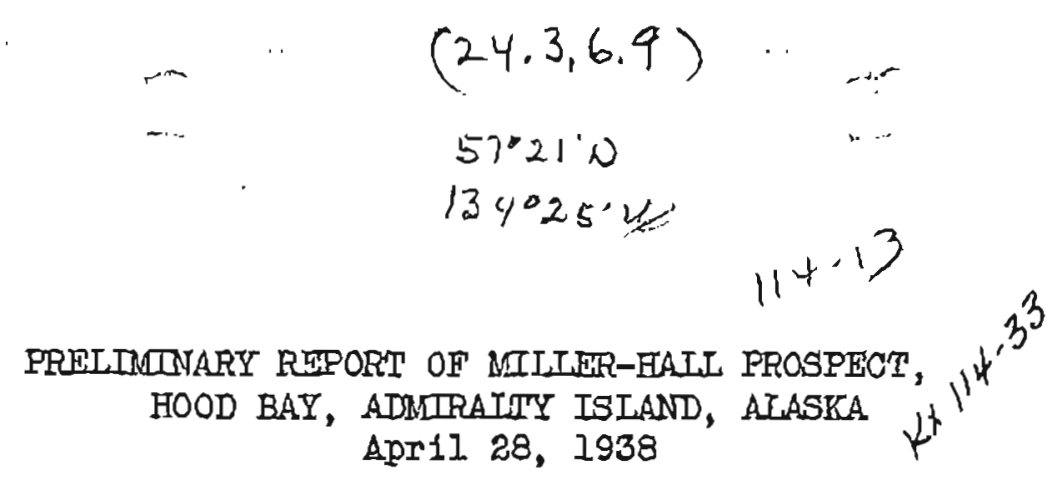

Location and Accessibllity:

The Millerinall gold prospect is looated on the south shore of a small bay, on the south slde of Hood Bay, 2 miles west of the junction of the north and south arms, and $1 \frac{1}{2}$ miles due west and across the bay from the Hood Bey cannery. The two quartz showings are located on the beach. Hood Bay is navigable to ocean-golng vessels as far inland as the cannery.

History:

This prospect was reported as having been found several years ago, at which time it was sampled by a representative of the Alaska Juneau mine. Small returns were apparently obtalned, as no work other than some strlpping was done. J. D. Miller $\operatorname{csme}$ upon this showing in the fall of 1937 and did some work, consloting of trenching and rock cuts. The writer was requested to investigate the showlngs and determine if sala showing contained indications that would warrant staking and further work. M1th the poor results obtained from the sampling, the writer advised the discontinuance of further work.

\title{
Shovsings and Geology:
}

The showlngs consiat of two large quartz outcroppings 400 feet apart. No. I showing, located on the south shore of the small bay, consists of a continuous quartz outcrop 80 feat abovo driftwood level. The width could not be determined. The outcrop extends in a northeast-southwest direction, nearly at right angle to the formation. The quartz lense is in greenstone schlst and ends to the west against a dark banded graphltic schist. The contact of the two formations strikes N. 450N. and the $\mathrm{dip}$ is steop to the west. There has not been sufficlent work to determine the structure on whlch this apparent quartz lense was formed. It may, as does No. 2 showing, occupy the crest of a fold. The quartz is glassy to milky white in appearance, and highly crystalline in nature. It is cross-fractured and the fractures are iron stainad. Generally it is nearly barren of mineralization. Three short cuts were made Into this showing, one on each end and one alongside.

No. 2 showlng is a simllar quartz showing, located 400 leet northwest of No. 1. Its location is between high and low tide levels sround the point west of the smell bay on the south shore of Hood Bay. This outcrop has a length of 80 peet, varles from 6 to 8 feet in thickess, and is folded. The structure of the formations here show a very decided 
complex of folded greenstone lava schists, agglomerates, endesitic lavas and other volcantc rocks, some of phich are high in silica content. This complex serles of formations are neer the contect of phyllites and Iimertono sediments. This outcrop strikes northesat and has a flat dip to the north. The quartz is nearly barren of mineralization, with a small amount of flne pyrite along the walls. No work hag been done on this showing and due to the barren nature, no samples wore taken. No. 1 showing:

The samples shown on the following assay sheet were taken on

ASSAY SHFRT

\begin{tabular}{|c|c|c|c|c|c|}
\hline Samplo & & & & Ounces & per ton \\
\hline No. & Location & Description & Width & Gold & SIIVer \\
\hline 356 & $\begin{array}{l}\text { Center cut No. } 2 \\
\text { alongside quertz }\end{array}$ & $\begin{array}{l}\text { Aoross quartz in } \\
\text { cut }\end{array}$ & 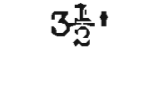 & Nil & N11 \\
\hline 357 & $\begin{array}{l}\text { Center cut No. } 2 \\
\text { west side of out }\end{array}$ & Across quartz & $5 \frac{\frac{1}{2}}{\mathbf{n}^{\prime}}$ & $"$ & 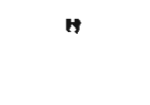 \\
\hline 358 & $\begin{array}{l}\text { Cut No. } 1 \text { east } \\
\text { end of quartz }\end{array}$ & $\begin{array}{l}\text { Across rineralized } \\
\text { greenstone schist }\end{array}$ & $2 \frac{1}{2}$ & $n$ & $"$ \\
\hline 359 & $\begin{array}{l}\text { Cut No. 1, west } \\
\text { wall }\end{array}$ & Across axposed quartz & $3 \frac{I}{2}^{\prime}$ & $"$ & " \\
\hline 360 & $\begin{array}{l}\text { Cut No. } 3 \text {, west } \\
\text { ond of quartz. } \\
\text { faos of cut }\end{array}$ & $\begin{array}{l}\text { Across fractured } \\
\text { quartz }\end{array}$ & $3 \cdot 10^{n}$ & 0.02 & $"$ \\
\hline 361 & $\begin{array}{l}\text { Cut No. } 3 \text {, west } \\
\text { end of quartz }\end{array}$ & $\begin{array}{l}\text { Grab sample of } \\
\text { mineralized quartz } \\
\text { pleces }\end{array}$ & & Trace & $n$ \\
\hline
\end{tabular}

